\title{
Fructus Xanthii extract protects against cytokine-induced damage in pancreatic B-cells through suppression of $\mathrm{NF}-\mathrm{kB}$ activation
}

\author{
MI-YOUNG SONG ${ }^{1 *}$, EUN-KYUNG KIM ${ }^{1 *}$, HEON-JAE LEE ${ }^{2 *}$, JIN-WOO PARK $^{1}$, \\ DO-GON RYU ${ }^{2}$, KANG-BEOM KWON ${ }^{2}$ and BYUNG-HYUN PARK ${ }^{1}$ \\ ${ }^{1}$ Department of Biochemistry, Medical School and Institute for Medical Sciences, Chonbuk National University, \\ Jeonju, Jeonbuk 561-756; ${ }^{2}$ Department of Physiology, School of Oriental Medicine, \\ College of Medicine, Wonkwang University, Iksan, Jeonbuk 570-749, Korea
}

Received November 21, 2008; Accepted January 21, 2009

DOI: 10.3892/ijmm_00000163

\begin{abstract}
Cytokines released by infiltrating inflammatory cells around the pancreatic islets are involved in the pathogenesis of type 1 diabetes. Interleukin (IL)- $1 \beta$ and interferon (IFN)- $\gamma$ are the primary cytokines responsible for stimulation of inducible nitric oxide synthase (iNOS) expression and nitric oxide overproduction, which leads to $B$-cell damage. In addition, nuclear factor $-\kappa \mathrm{B}(\mathrm{NF}-\kappa \mathrm{B})$ plays a crucial role in the activation of this pathway. Therefore, suppression of the cytokine-NF- $\mathrm{B}$ pathway is considered an effective therapeutic strategy for preventing inflammatory reactions in pancreatic $\beta$-cells. In this study, the effects of Fructus Xanthii extract (FXE) on IL-1ß and IFN- $\gamma$-induced $\beta$-cell damage were examined. Treatment of RINm5F cells with IL-1B and IFN- $\gamma$ reduced cell viability, however, FXE completely protected cells from IL-1ß and IFN- $\gamma$-mediated reduction in viability in a concentrationdependent manner. In addition, incubation with FXE resulted in a significant suppression of IL- $1 \beta$ and IFN- $\gamma$-induced nitric oxide (NO) production, which correlated with the reduced levels of the inducible form of iNOS mRNA and protein observed. The IL- $1 \beta$ and IFN- $\gamma$-stimulated RIN cells showed increases in $\mathrm{NF}-\kappa \mathrm{B}$ binding activity and p50 subunit levels in the nucleus, as well as increased $\mathrm{I} \kappa \mathrm{B} \alpha$ degradation in cytosol when compared to unstimulated cells, which indicates that the mechanism by which FXE inhibited the iNOS gene involves inhibition of NF- $\mathrm{KB}$ activation. Furthermore, a protective effect
\end{abstract}

Correspondence to: Dr Byung-Hyun Park, Medical School, Chonbuk National University, Jeonju, Jeonbuk 561-756, Korea

E-mail: bhpark@chonbuk.ac.kr

Dr Kang-Beom Kwon, School of Oriental Medicine, Wonkwang University, Iksan, Jeonbuk 570-749, Korea

E-mail: desson@wonkwang.ac.kr

${ }^{*}$ Contributed equally

Key words: Fructus Xanthii, NF-кB, iNOS, cytokine of FXE was demonstrated by reduction in NO generation and iNOS expression, as well as the normal insulin secreting responses to glucose observed in IL- $1 \beta$ and IFN- $\gamma$-treated islets.

\section{Introduction}

Autoimmune insulitis, which is the infiltration of inflammatory cells within and around the pancreatic islets, is the primary characteristic of type 1 (insulin-dependent) diabetes (1). In this process, proinflammatory agents, such as cytokines and free radicals, are released from the infiltrated inflammatory cells. It was previously reported that interleukin (IL)-1ß, either alone or in combination with tumor necrosis factor- $\alpha$ or interferon (IFN) $-\gamma$, induces the expression of inducible nitric oxide synthase (iNOS) in B-cells, which leads to overproduction of nitric oxide (NO) that mediates the inhibition of insulin secretion and cytotoxicity of $\beta$-cells (2-5). This time-dependent inhibitory action of IL-1ß on islet function correlates with the timedependent expression of iNOS and the production of nitric oxide (NO) (6). NO is a short-lived and highly reactive radical that inhibits the Krebs-cycle enzyme aconitase and the electron transport chain complexes I and II, thereby leading to decreased glucose oxidation rates, ATP generation and insulin production (7-9). iNOS inhibitors, such as $N^{\mathrm{w}}$-nitro-L-arginine methylester (L-NAME) and aminoguanidine, prevent the inhibitory actions of IL-1ß on islet oxidative metabolism and secretory function (10). Although IFN- $\gamma$ alone does not stimulate iNOS expression in rat islets, it does prime them for IL-1ß-induced iNOS expression (11).

The inhibitory actions of IL-1ß on islets are associated with the expression of various genes activated by nuclear factor- $\mathrm{kB}$ $(\mathrm{NF}-\kappa \mathrm{B})$, a transcription factor. The long exposure of islets to IL-1ß stimulates various $\mathrm{NF}-\kappa \mathrm{B}-$ mediated genes, including iNOS and cyclooxygenase-2 $(5,12)$, however, phosphorylation and proteolytic degradation of $\mathrm{I} \kappa \mathrm{B}$ is required for $\mathrm{NF}-\kappa \mathrm{B}$ activation to occur. NF- $\mathrm{BB}$ is initially located in the cytosol complexed with IкB in an inactive form. Various inducers cause dissociation of this complex, presumably via phosphorylation of IкB, which causes $\mathrm{NF}_{-} \kappa \mathrm{B}$ to be released from the complex. NF- $\mathrm{BB}$ then translocates to the nucleus, where it interacts with specific DNA recognition sites to mediate gene transcription (13-15). 
Fructus Xanthii, which is the fruit of Xanthium strumarium L. and belongs to the Compositae family, is known to clear the nasal passages and alleviate symptoms of the common cold. To our knowledge, however, the antidiabetic effects of FXE have not yet been reported. Therefore, this study was conducted to investigate the effect of FXE on IL- $1 \beta$ and IFN- $\gamma$-induced ß-cell damage, with a focus on the effect of FXE on iNOS expression. The results of this study show that FXE inhibited IL-1ß and IFN- $\gamma$-induced NF- $\kappa$ B activation, iNOS expression, NO production, glucose-stimulated insulin secretion (GSIS) and cell death in B-cells, which may explain the beneficial effects of FXE as an anti-diabetic agent.

\section{Materials and methods}

Cell culture and reagents. RINm5F (RIN) cells were purchased from the American Type Culture Collection and grown at $37^{\circ} \mathrm{C}$ under a humidified, $5 \% \mathrm{CO}_{2}$ atmosphere in RPMI-1640 medium (Gibco BRL, Grand Island, NY) supplemented with $10 \%$ fetal bovine serum, $2 \mathrm{mM}$ glutamine, $100 \mathrm{U} / \mathrm{ml}$ of penicillin, $100 \mu \mathrm{g} / \mathrm{ml}$ of streptomycin, and $2.5 \mu \mathrm{g} / \mathrm{ml}$ of amphotericin B. IL-1ß and IFN- $\gamma$ were obtained from R\&D (Minneapolis, MN). All reagents were purchased from Sigma (St. Louis, MO) unless otherwise noted.

Preparation of Fructus Xanthii extract. The plant was purchased from Wonkwang Oriental Medical Hospital in Iksan, Jeonbuk, Korea and identified as Fructus Xanthii by Ho-Joon Song, keeper of the Herbarium. Voucher samples were preserved for reference in the Herbarium of the Department of Physiology, School of Oriental Medicine, Wonkwang University. For extraction, $200 \mathrm{~g}$ of Fructus Xanthii were ground and extracted in boiling water for $4 \mathrm{~h}$. The sample was then centrifuged at 3,000 $\mathrm{x}$ g for $20 \mathrm{~min}$, after which the supernatant was concentrated under reduced pressure to $200 \mathrm{ml}$ and then freeze dried to $18.24 \mathrm{~g}$. The sterile extract was stored at $-70^{\circ} \mathrm{C}$.

MTT assay for cell viability. The viability of cultured cells was determined by assaying the reduction of 3-(4,5-dimethylthiazol2-yl)-2,5-diphenyltetrazolium bromide (MTT) to formazan. Briefly, RIN cells were seeded overnight in 96-well tissue culture plates with clear, flat bottoms (Becton-Dickinson, Franklin Lakes, NJ) at a density of $1 \times 10^{5}$ cells per well in $100 \mu 1$ of medium. Cells were then pretreated with various concentrations of FXE or $1 \mathrm{mM} \mathrm{L-NAME}$ for $3 \mathrm{~h}$, and then IL-1ß $(2 \mathrm{ng} / \mathrm{ml})$ and IFN- $\gamma(100 \mathrm{U} / \mathrm{ml})$ were added for an additional $48 \mathrm{~h}$. Next, cells were washed twice with PBS, after which MTT $(100 \mu \mathrm{g} / 100 \mu \mathrm{l}$ of PBS) was added. Next, the cells were incubated at $37^{\circ} \mathrm{C}$ for $1 \mathrm{~h}$, and then DMSO $(100 \mu \mathrm{l})$ was added to dissolve the formazan crystals. The absorbance at $570 \mathrm{~nm}$ was then measured using a model Spectra MAX PLUS spectrophotometer (Molecular Devices, Sunnyvale, CA).

5-Bromo-2-deoxyuridine (BrdU)-labeling cell proliferation assay. A cell proliferation enzyme-linked immunosorbant assay (BrdU kit, Amersham Biosciences, Piscataway, NJ) was used to measure the incorporation of BrdU during DNA synthesis following the manufacturer's protocols. Briefly, RIN cells $\left(1 \times 10^{5}\right)$ were pretreated with the indicated concentrations of
FXE or $1 \mathrm{mM} \mathrm{L-NAME}$ for $3 \mathrm{~h}$, after which IL-1ß (2 ng/ml) and IFN- $\gamma(100 \mathrm{U} / \mathrm{ml})$ were added. Following $48 \mathrm{~h}$ of incubation, BrdU $(10 \mu \mathrm{M})$ was added to the culture medium for $2 \mathrm{~h}$, after which BrdU-labeled cells were fixed. The DNA was then denatured in fixative solution for $30 \mathrm{~min}$ at room temperature, followed by incubation of cells with peroxidaseconjugated anti-BrdU antibody for $2 \mathrm{~h}$ at room temperature. Cells were then washed three times with washing solution, after which the immune complex was detected using a 3,3',5,5'-tetramethylbenzidine substrate reaction and the absorbance was measured at $405 \mathrm{~nm}$ using a Spectra MAX PLUS spectrophotometer.

Nitrite measurement. Biologically produced NO is rapidly oxidized to nitrite and nitrate in aqueous solutions. Therefore, NO production was evaluated by measuring nitrite concentrations in the cell-free culture supernatant using a colorimetric assay. Briefly, RIN cells $\left(5 \times 10^{5}\right)$ were pretreated with the indicated concentrations of FXE for $3 \mathrm{~h}$, and then IL-1ß $(2 \mathrm{ng} / \mathrm{ml})$ and IFN- $\gamma(100 \mathrm{U} / \mathrm{ml})$ were added. Following $24 \mathrm{~h}$ of incubation, $100 \mu \mathrm{l}$ aliquots of the culture supernatants were incubated with $100 \mu \mathrm{l}$ of a modified Griess reagent (1:1 mixture of $1 \%$ sulfanilamide in $30 \%$ acetic acid and $0.1 \% \mathrm{~N}$-(1-naphthyl) ethylenediamine dihydrochloride in $60 \%$ acetic acid) at room temperature for $5 \mathrm{~min}$, at which time the absorbance at 540 $\mathrm{nm}$ was measured using a spectro-photometer (Ultrospec 2100 pro, Amersham Biosciences). The concentrations of NO were then determined using a linear standard curve generated from serial dilutions of sodium nitrite in working medium.

Isolation of islets. Pancreatic islets were isolated from male Sprague-Dawley rats by collagenase digestion, as described previously (16). Following isolation, the islets were cultured overnight in RPMI-1640 supplemented with $2 \mathrm{mM} \mathrm{L-glutamine,}$ $10 \%$ heat-inactivated fetal calf serum, $100 \mathrm{U} / \mathrm{ml}$ penicillin, and $100 \mu \mathrm{g} / \mathrm{ml}$ streptomycin in a humidified atmosphere containing $5 \% \mathrm{CO}_{2}$ at $37^{\circ} \mathrm{C}$. Prior to each experiment, islets were washed three times in RPMI-1640, counted, and then cultured overnight.

Glucose-stimulated insulin secretion assay. Islets were cultured for $24 \mathrm{~h}$ with IL-1ß and IFN- $\gamma$ in the presence or absence of FXE. Next, the islets were washed three times in Krebs-Ringer bicarbonate buffer (25 mM Hepes, $115 \mathrm{mM} \mathrm{NaCl}, 24 \mathrm{mM}$ $\mathrm{NaHCO}_{3}, 5 \mathrm{mM} \mathrm{KCl}, 1 \mathrm{mM} \mathrm{MgCl}$, $2.5 \mathrm{mM} \mathrm{CaCl}_{2}$, and $0.1 \%$ bovine serum albumin, $\mathrm{pH}$ 7.4) containing $3 \mathrm{mM}$ D-glucose, after which insulin secretion was measured by static incubation of the islets for $30 \mathrm{~min}$ in the presence of either 5.5 or $20 \mathrm{mM}$ D-glucose. The insulin content of the medium was then determined by ELISA (Linco Research, St. Charles, MO).

Western blot analysis. Cells were homogenized in $100 \mu 1$ of ice-cold lysis buffer (20 mM Hepes, pH 7.2, 1\% Triton X-100, $10 \%$ glycerol, $1 \mathrm{mM}$ phenylmethylsulfonyl fluoride (PMSF), $10 \mu \mathrm{g} / \mathrm{ml}$ leupeptin, $10 \mu \mathrm{g} / \mathrm{ml}$ aprotinin). The homogenates, which contained $20 \mu \mathrm{g}$ of protein, were then separated by SDS-PAGE with $7.5 \%$ (for iNOS) or $12 \%$ resolving (for IкB $\alpha$, p50, $\beta$-actin, and PCNA) and 3\% acrylamide stacking gels, and then transferred to nitrocellulose membranes. The blots were blocked with $2 \%$ bovine serum albumin and then 
A

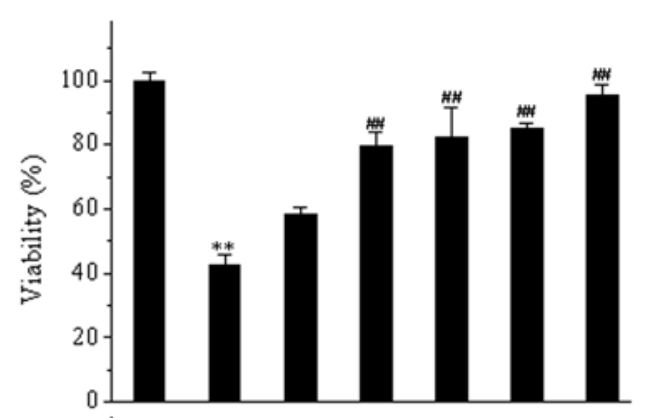

B

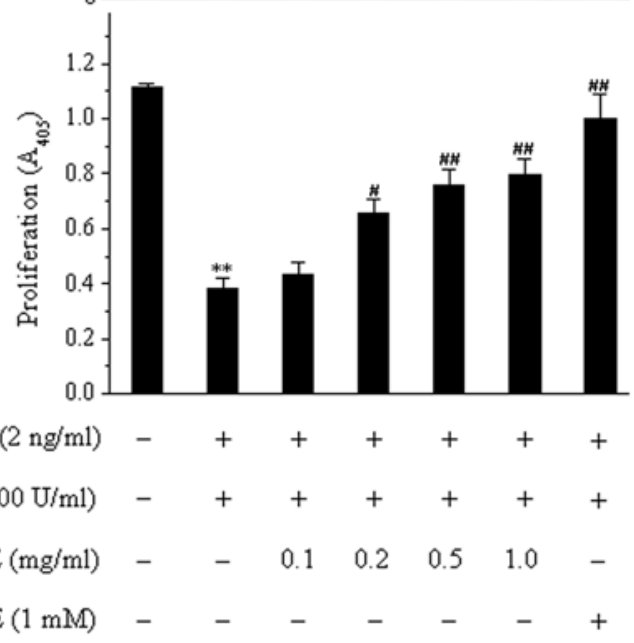

Figure 1. Prevention of IL-1ß and IFN- $\gamma$-induced cell death by FXE. RIN cells $\left(1 \times 10^{5}\right)$ were pretreated with the indicated concentrations of FXE or L-NAME for $3 \mathrm{~h}$, and then IL- $1 ß$ and IFN- $\gamma$ were added for $48 \mathrm{~h}$. The cell viability and proliferative potential were then determined using an MTT (A) and BrdU incorporation assay (B), respectively, as described in Materials and methods. Each value represents the mean \pm SEM of three independent experiments. ${ }^{* *} \mathrm{p}<0.01$ vs. untreated control; ${ }^{\#} \mathrm{p}<0.05,{ }^{\#} \mathrm{p}<0.01$ vs. IL- $1 \beta+\mathrm{IFN}-\gamma$.

incubated for $4 \mathrm{~h}$ with $1 \mu \mathrm{g} / \mathrm{ml}$ of primary antibody (Santa Cruz Biochemicals, Santa Cruz, CA) and then detected with horseradish peroxidase-conjugated IgG (Zymed, South San Francisco, CA).

RNA isolation and real-time PCR. Total RNA was isolated from RIN cells or islets using Trizol reagent (Invitrogen, Carlsbad, CA). RNA was then precipitated with isopropanol and dissolved in DEPC-treated distilled water. Next, total RNA $(2 \mu \mathrm{g})$ was treated with RNase-free DNase (Invitrogen), after which first-strand cDNA was generated using the random hexamer primer provided in the first-strand cDNA synthesis kit (Applied Biosystems, Foster City, CA). The following specific primers for iNOS (accession No. NM_012611) were designed using the primer express software (Applied Biosynthesis): iNOS, 5'-TGTGCTAATGCGGAAGGTCAT-3' (forward), and 5'-CGACTTTCCTGTCTCAGTAGCAAA-3' (reverse). The sequence for the control $18 \mathrm{~S}$ ribosomal RNA was purchased from Applied Biosystems and used as the invariant control. The real-time PCR reaction, which was contained in a final volume of $10 \mu \mathrm{l}$, consisted of $10 \mathrm{ng}$ of reverse transcribed total RNA, $167 \mathrm{nM}$ of forward and reverse primers and $2 \times$ PCR master mixture. PCR was conducted in 384-well plates using the ABI Prism 7900HT Sequence Detection System (Applied Biosystems). All reactions were conducted in triplicate.
Preparation of nuclear protein extracts. Cells were washed with PBS and then lysed in CytoBuster ${ }^{\mathrm{TM}}$ Protein Extraction Buffer (Novagen). Next, the lysate was centrifuged at 10,000 x g for $5 \mathrm{~min}$ at $4^{\circ} \mathrm{C}$, and the supernatant was then used as the whole cell protein extract. Cytoplasmic and nuclear extracts were prepared from RINm5F cells using the NE-PER ${ }^{\circledR}$ Nuclear and Cytoplasmic Extraction Reagents (Pierce Biotechnology, Rockford, IL) according to the manufacturer's instructions.

Electrophoretic mobility shift assay (EMSA). The activation of $\mathrm{NF}-\kappa \mathrm{B}$ was assayed by a gel mobility shift assay using nuclear extracts from control and treated cells. An oligonucleotide containing the $\kappa$-chain binding site $(\mathrm{\kappa B}, 5$ '-CCGGTTAACA GAGGGGGCTTTCCGAG-3') was synthesized and used as a probe for the gel retardation assay. The two complementary strands were then annealed and labeled with $\left[\alpha^{-32} \mathrm{P}\right] \mathrm{dCTP}$. The labeled oligonucleotides $(10,000 \mathrm{cpm}), 10 \mu \mathrm{g}$ of nuclear extracts, and binding buffer $(10 \mathrm{mM}$ Tris- $\mathrm{HCl}, \mathrm{pH} 7.6,500 \mathrm{mM}$ $\mathrm{KCl}, 10 \mathrm{mM}$ EDTA, 50\% glycerol, $100 \mathrm{ng}$ poly(dI·dC), $1 \mathrm{mM}$ dithiothreitol) were then incubated for $30 \mathrm{~min}$ at room temperature in a final volume of $20 \mu \mathrm{l}$. Next, the reaction mixtures were analyzed by electrophoresis on $4 \%$ polyacrylamide gels in $0.5 \mathrm{x}$ Tris-borate buffer. The gels were then dried and examined by autoradiography. Specific binding was controlled by competition with a 50 -fold excess of cold $\mathrm{\kappa B}$ oligonucleotide.

Statistical analysis. Statistical analysis of the data was performed using ANOVA and Duncan's test. Differences with a $\mathrm{p}<0.05$ were considered statistically significant.

\section{Results}

Prevention of IL-1 $\beta$ and IFN- $\gamma$-induced cell death by FXE. RIN cells from a rat pancreatic $\beta$-cell line were cultured to near confluence. Cells that were pretreated with or without FXE for $3 \mathrm{~h}$ were then exposed to IL-1ß $(2 \mathrm{ng} / \mathrm{ml})$ and IFN- $\gamma(100 \mathrm{U} / \mathrm{ml})$ for $48 \mathrm{~h}$, at which time they were harvested and their viability assessed using an MTT assay. Treatment with IL- $1 \beta$ and IFN $-\gamma$ significantly reduced cell viability to $42.4 \pm 3.2 \%$ of the control (Fig. 1A). Conversely, pretreatment with FXE increased viability of IL- $1 \beta$ and IFN- $\gamma$-treated RIN cells in a concentration-dependent manner. The protective effect of FXE on IL-1 13 and IFN- $\gamma$-induced cytotoxicity was further confirmed by measuring the BrdU incorporation in RIN cells. After incubation with cytokines for $48 \mathrm{~h}$, the level of BrdU incorporation, and therefore proliferation, was reduced to $34.3 \pm 3.26 \%$ of the control levels (Fig. 1B). Similar to the results of the MTT assay, pretreatment with FXE prevented the IL-1 13 and IFN- $\gamma$-mediated decrease in proliferative potential. Viability was not affected when RIN cells were treated with FXE at any of the concentrations used (data not shown).

Effect of FXE on IL-1 $\beta$ and IFN- $\gamma$-induced NO production by RIN cells. It was reported that IL- $1 \beta$ and IFN- $\gamma$-mediated destruction of $\beta$-cells is caused by an increase of $\mathrm{NO}(5,6)$. In this study, incubation of RIN cells with IL-1ß and IFN- $\gamma$ for $24 \mathrm{~h}$ resulted in significant production of nitrite (a stable oxidized product of NO) by these cells. However, the presence of FXE significantly diminished the IL-1ß and IFN- $\gamma$-mediated 


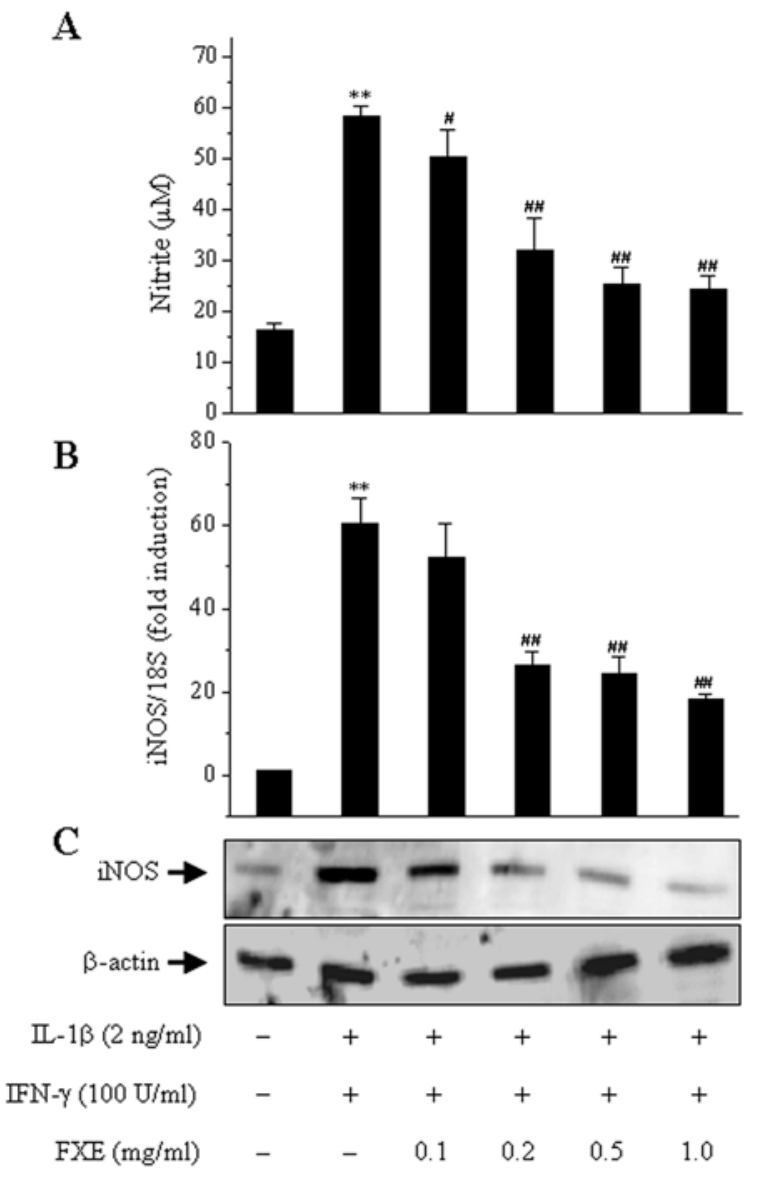

Figure 2. Effect of FXE on IL-1ß and IFN- $\gamma$-induced NO production and iNOS mRNA and protein expression. RIN cells $\left(5 \times 10^{5}\right)$ were pretreated with the indicated concentrations of FXE for $3 \mathrm{~h}$, and then IL- $1 \beta$ and IFN- $\gamma$ were added. The level of nitrite was then measured in the cell-free culture supernatants after $24 \mathrm{~h}$ of incubation (A). RIN cells $\left(5 \times 10^{6}\right)$ were pretreated with the indicated concentrations of FXE for $3 \mathrm{~h}$, after which IL-1B and IFN- $\gamma$ were added for $24 \mathrm{~h}$. Real-time PCR (B) and Western blotting (C) for iNOS were then conducted. The results of three independent experiments are expressed as the mean \pm SEM. ${ }^{* *} \mathrm{p}<0.01$ vs. untreated control; ${ }^{\#} \mathrm{p}<0.05,{ }^{\#} \mathrm{p}<0.01$ vs. IL- $1 \beta+$ IFN- $\gamma$.

nitrite production (Fig. 2A), and this reduction was well correlated with the lowered cytotoxicity of the cells (Fig. 1). To examine whether FXE inhibited NO production via suppression of iNOS gene expression, changes in the expression of iNOS mRNA and proteins were investigated by real-time PCR and Western blot analysis, respectively. iNOS mRNA and protein expression were markedly increased in cells treated with IL-1ß and IFN- $\gamma$, whereas cells pretreated with FXE showed suppressed expression of both the mRNA and protein levels of iNOS (Fig. 2B and C), and this occurred in a concentration-dependent manner. Furthermore, addition of L-NAME, an inhibitor of iNOS, completely prevented the IL-1ß and IFN- $\gamma$-induced cytotoxicity (Fig. 1). These results indicate that the cytoprotective effect of FXE against IL-1ß and IFN- $\gamma$ occurred due to suppression of iNOS expression.

Effect of FXE on IL-1 $\beta$ and IFN- $\gamma$-induced $N F-\kappa B$ activation. Because NF- $\mathrm{BB}$ is implicated in the transcriptional regulation of cytokine-induced iNOS expression, we studied the effect of FXE on IL- $1 \beta$ and IFN- $\gamma$-stimulated translocation of NF- $\mathrm{BB}$ from the cytosolic compartment to the nucleus and on DNA

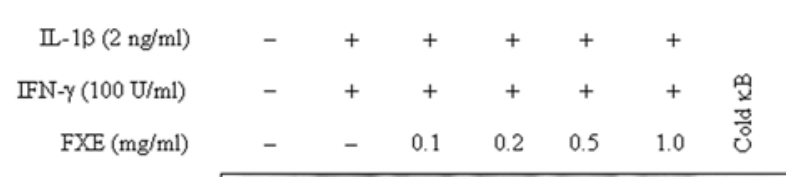

A

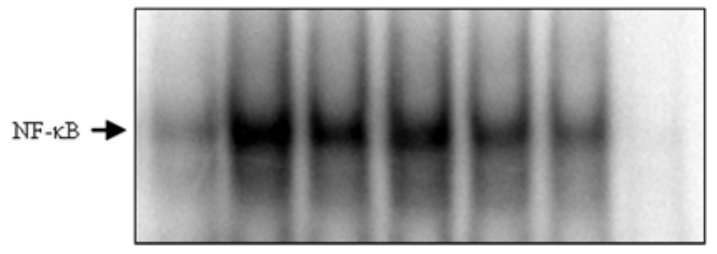

B

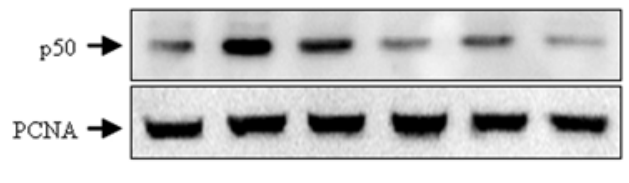

C

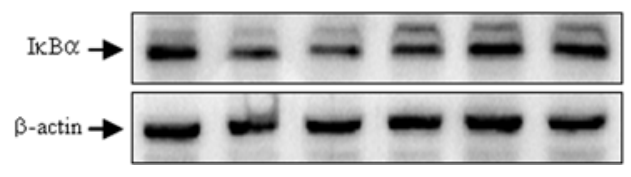

Figure 3. Effect of FXE on IL-1ß and IFN- $\gamma$-induced DNA binding of NF-кB, translocation of $\mathrm{p} 50$ to the nucleus, and $\mathrm{I} \kappa \mathrm{B} \alpha$ degradation. RIN cells $\left(5 \times 10^{6}\right)$ were pretreated with the indicated concentrations of FXE for $3 \mathrm{~h}$, and then IL- $1 \beta$ and IFN- $\gamma$ were added. Following 30 min of incubation, DNA binding of NF- $\mathrm{KB}$ was analyzed by EMSA (A), and the translocation of p50 to the nucleus (B) and IкB $\alpha$ degradation in the cytosol (C) were determined by Western blotting. PCNA was used as loading control for nuclear protein. Results are representative of three separate experiments.

binding in RIN cells. IL-1ß and IFN- $\gamma$-treated RIN cells showed increased binding activity of an NF- $\kappa$ B consensus sequence (Fig. 3A), as well as increased p50 subunit levels in their nuclei (Fig. 3B) when compared to unstimulated cells. Additionally, IL- $1 \beta$ and IFN- $\gamma$-induced NF- $\kappa$ B activation was markedly suppressed by pretreatment with FXE, which suggests that FXE inhibits iNOS expression through the inhibition of NF- $\kappa \mathrm{B}$ activation. The specificity of DNA-protein interactions for $\mathrm{NF}-\kappa \mathrm{B}$ was demonstrated by performing competition assays using a 50-fold excess of unlabeled oligonucleotide (Fig. 3A, lane 7).

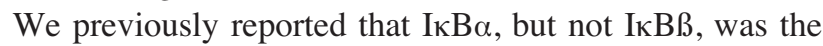
major participant in IL-1B and IFN- $\gamma$ induced NF- $\kappa$ B activation (17). Therefore, we investigated the alteration of IкB $\alpha$ levels in the cytosol fraction after IL-1ß and IFN- $\gamma$ treatment (Fig. 3C). IL-1B and IFN- $\gamma$-treated RIN cells showed a decreased level of $\mathrm{I} \kappa \mathrm{B} \alpha$ protein in the cytosol when compared to a similar fraction in the unstimulated cells, however, the increased IкB $\alpha$ degradation as a result of IL- $1 \beta$ and IFN- $\gamma$ treatment was markedly suppressed by treatment with FXE, and this effect occurred in a concentration-dependent manner.

Inhibition of $I L-1 \beta$ and IFN- $\gamma$-induced $N F-\kappa B$ pathways by $F X E$ in rat islets. We assessed the preventive effects of FXE using rat pancreatic islets isolated from male Sprague-Dawley rats to support the physiological importance of the results obtained in the cell line studies. Incubation of the rat islets with cytokines for $24 \mathrm{~h}$ resulted in a 3.5 -fold increase in $\mathrm{NO}$ production (Fig. 4A). Additionally, real-time PCR and Western blotting data showed that iNOS mRNA and protein levels were markedly increased by IL-1B and IFN- $\gamma$ (Fig. 4B and C). Similar to the results obtained using the RIN cells, pretreatment 
A

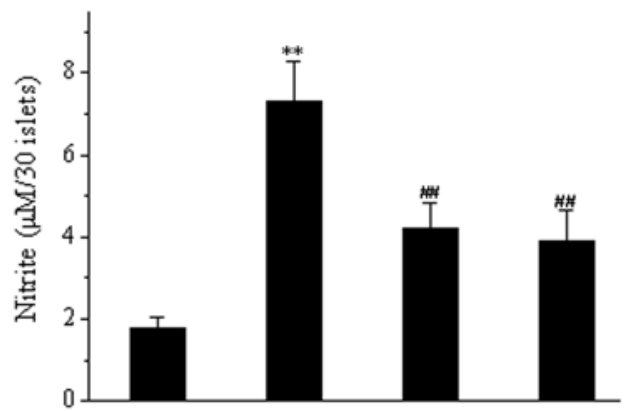

B

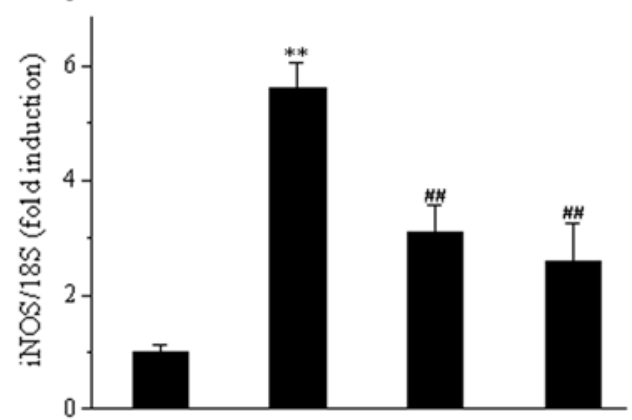

C

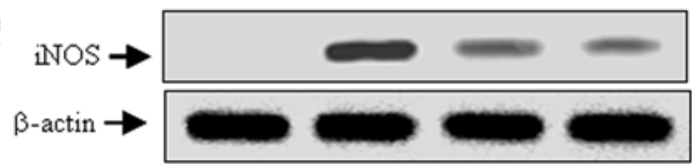

II-1ß $(2 \mathrm{ng} / \mathrm{ml})$

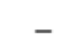

IFN- $\gamma(100 \mathrm{U} / \mathrm{ml})$

FXE $(\mathrm{mg} / \mathrm{ml})$

$-$

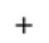

$+$

$-$

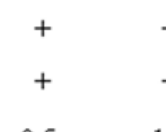

0.5

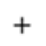

$+$ 1.0
Figure 4. Inhibition of FXE on IL-1ß and IFN- $\gamma$-induced NO production and iNOS expression in rat islets. Rat islets (30 islets total) were treated with IL-1 13 and IFN- $\gamma$ with or without a $3 \mathrm{~h}$ pretreatment with FXE. Following $24 \mathrm{~h}$ of incubation, NO production (A), iNOS mRNA (B) and protein expression (C) were determined. Western blotting data are representative of three separate experiments. The results of three independent experiments are expressed as the mean \pm SEM. ${ }^{* *} \mathrm{p}<0.01$ vs. untreated control; ${ }^{\# \#} \mathrm{p}<0.01$ vs. IL- $1 \beta+$ IFN- $\gamma$.

of the islets with FXE abolished the effects of IL-1ß and IFN- $\gamma$, and resulted in suppressed levels of NO production and iNOS expression that were similar to those of the control.

Preservation of GSIS by FXE in the presence of $I L-1 \beta$ and $I F N-\gamma$. Our results consistently showed a suppressive effect of FXE on IL-1ß and IFN- $\gamma$-induced NF- $\mathrm{KB}$-regulated gene expression. To add functional data, we determined whether FXE also protects against cytokine-induced impairment of GSIS. After $24 \mathrm{~h}$ of exposure to IL- $1 \beta$ and IFN- $\gamma$, the level of insulin secretion in response to $20 \mathrm{mM}$ of glucose was determined. Control islets were found to secrete insulin at a concentration of $10.6 \pm 2.1 \mathrm{ng} / \mathrm{ml}$, whereas insulin secretion from IL- $1 \beta$ and IFN- $\gamma$-treated islets decreased significantly to $5.23 \pm 1.1 \mathrm{ng} / \mathrm{ml}(\mathrm{p}<0.05)$ (Fig. 5). However, pretreatment with FXE blocked the effect of the cytokines and restored islet cell insulin secretion to levels similar to that of the controls.

\section{Discussion}

In this study, we examined the preventive effects of FXE on IL-1ß and IFN- $\gamma$-induced $\beta$-cell damage. The results of MTT and $\mathrm{BrdU}$ incorporation assays showed that rat insulinoma

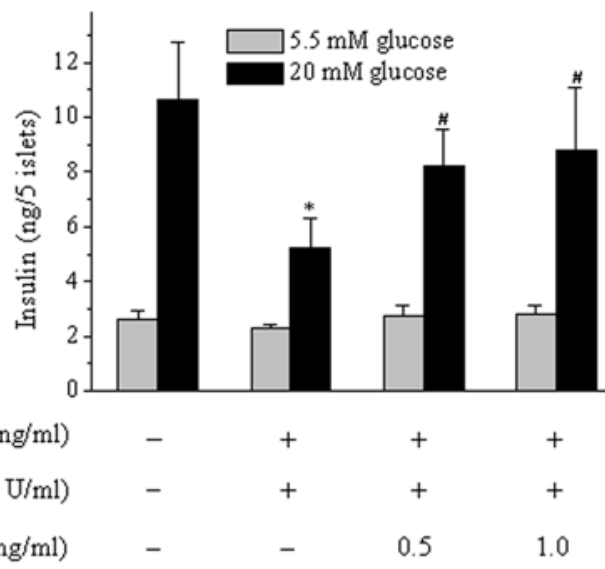

Figure 5. Effects of FXE on IL-1ß and IFN- $\gamma$-induced inhibition of glucosestimulated insulin secretion. Rat islets ( 5 islets $/ 500 \mu 1)$ were treated with IL- 13 and IFN- $\gamma$ with or without a $3 \mathrm{~h}$ pretreatment with FXE. Following $24 \mathrm{~h}$ of incubation, glucose-stimulated insulin secretion was quantified. The results of three independent experiments are expressed as the mean \pm SEM. ${ }^{*} \mathrm{p}<0.05$ vs. untreated control; ${ }^{\#} \mathrm{p}<0.05$ vs. IL- $1 \beta+\mathrm{IFN}-\gamma$.

cells pretreated with FXE were resistant to cytokine-induced cytotoxicity. The protective actions of FXE on cellular metabolism are associated with an inability of $\beta$-cells to express iNOS or produce NO in response to IL- $1 \beta$ and IFN- $\gamma$. Because both IL- $1 \beta$ and IFN- $\gamma$ are important mediators of $\beta$-cell death $(18,19)$, it was proposed that cytokine-NF-кB is a critical pathway for $\beta$-cell death in type 1 diabetes (20). The results of this study demonstrate that FXE prevents IL- $1 \beta$ and IFN- $\gamma$-induced NF-кB nuclear translocation. These findings indicate that FXE provides functional protection against the damaging effects of IL- $1 \beta$ and IFN- $\gamma$ by preventing NF- $\kappa \mathrm{B}$-activation.

It is well known that IL- $1 \beta$ and IFN- $\gamma$ induce iNOS expression and overproduction of $\mathrm{NO}$, which in turn leads to the dysfunction and destruction of $\beta$-cells $(5,6)$. The RIN cell is comparable to primary $\beta$-cells in the aspects of IL- $1 \beta$ and IFN- $\gamma$-mediated NO production, iNOS expression, and cytotoxicity (21). We observed that the responses of RIN cells to IL-1ß were similar to those of islets with respect to nitrite formation and iNOS protein expression, even though they lack the type 2 glucose transporter $(22,23)$. This result suggests that RIN cells are an appropriate substitute for primary $ß$-cells.

Pretreatment with FXE inhibited iNOS mRNA expression induced by IL- $1 \beta$ and IFN- $\gamma$, which implies that FXE regulates the expression of iNOS at the transcriptional level. NF- $\kappa \mathrm{B}$ is the primary transcription factor in the regulation of iNOS expression (5), and in this study, Western blot analysis showed that FXE inhibited IL- $1 \beta$ and IFN- $\gamma$-induced nuclear translocation of the p50 NF- $\kappa \mathrm{B}$ subunit. In addition, EMSA indicated that FXE inhibited IL- $1 \beta$ and IFN- $\gamma$-induced NF- $\mathrm{B}$ DNA binding activity. FXE prevented NF- $\kappa \mathrm{B}$ activation through prevention of IкB degradation. It is also possible that

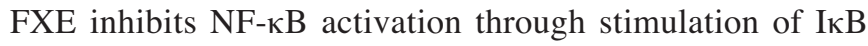
kinase. Regardless of the mechanism, however, the net result of each event is the sequestration of NF- $\mathrm{KB}$ in the cytoplasm and inhibition of the subsequent NF- $\mathrm{KB}$-dependent mRNA transcription, including the transcription of iNOS. Excessive NO production by overexpressed iNOS genes was reported in acute and chronic disease states, including type 1 diabetes 
$(24,25)$. Currently, it is important to conduct studies that focus on the repression of NF- $\mathrm{KB}$ or its downstream events to protect B-cells from various kinds of insults. We already reported the protective effect of a variety of natural compounds and herbs against cytokine-induced $\beta$-cell damage through suppression of NF- $\mathrm{BB}$ activation $(22,26-28)$, and many other studies were conducted in an attempt to save B-cells from cytokine or cytotoxin-induced damage by repressing either $\mathrm{NF}-\kappa \mathrm{B}$ activation or NF-кB dependent gene expression (29-31). However, in addition to iNOS, heat shock protein 70 , heme oxygenase, Mn-superoxide dismutase (32) and cyclooxygenase- $2(33,34)$ are also induced by NF- $\mathrm{KB}$ activation, all of which are stress response proteins known to be induced by cytokines, heat shock and oxidative stress. Therefore, we cannot exclude the possibility that FXE exerts a protective effect against cytokines through regulation of the aforementioned proteins.

Traditional plant medicines have been used for centuries in different regions of the world. Despite insufficient evidence to support its therapeutic efficacy, the use of herbal medicine has increased considerably due to the relatively non-toxic effects, low cost and availability of these treatments $(35,36)$. Fructus Xanthii, which is commonly used in Chinese medicine, was reported to have inhibitory effects on mast cell-mediated allergic reaction (37), as well as anti-inflammatory actions in lipopolysaccharide-stimulated inflammatory responses (38). To our knowledge, no other studies were conducted to evaluate the relationship of FXE with the prevention of $\beta$-cell damage in type 1 diabetes. Therefore, in this study, we focused on the effects of FXE on cytokine-induced B-cell damage using an insulinoma cell line and isolated pancreatic islets with the objective of elucidating the signaling mechanism through which they exert their effects. FXE rescued $\beta$-cells from cytokine toxicity, reversed impairment, and completely restored function by suppressing the NF-кB pathway. Taken together, our data suggest a possible role of Fructus Xanthii as a preventive or therapeutic agent against type 1 diabetes.

\section{Acknowledgements}

This work was supported by the Grant of the Korean Ministry of Education, Science and Technology (The Regional Core Research Program/Center for Healthcare Development Technology).

\section{References}

1. Andre I, Gonzalez A, Wang B, Katz J, Benoist C and Mathis D: Checkpoints in the progression of autoimmune disease: lessons from diabetes models. Proc Natl Acad Sci USA 93: 2260-2263, 1996.

2. Arnush M, Heitmeier MR, Scarim AL, Marino MH, Manning PT and Corbett JA: IL-1 produced and released endogenously within human islets inhibits $B$ cell function. J Clin Invest 102: 516-526, 1998

3. Cetkovic-Cvrlje M and Eizirik DL: TNF- $\alpha$ and IFN- $\gamma$ potentiate the deleterious effects of IL-1ß on mouse pancreatic islets mainly via generation of nitric oxide. Cytokine 6: 399-406, 1994.

4. Corbett JA and McDaniel ML: Intraislet release of interleukin 1 inhibits $\beta$ cell function by inducing $\beta$ cell expression of inducible nitric oxide synthase. J Exp Med 181: 559-568, 1995.

5. Flodstrom M, Welsh $\mathrm{N}$ and Eizirik DL: Cytokines activate the nuclear factor $\kappa \mathrm{B}(\mathrm{NF}-\kappa \mathrm{B})$ and induce nitric oxide production in human pancreatic islets. FEBS Lett 385: 4-6, 1996.
6. Eizirik DL, Flodstrom M, Karlsen AE and Welsh N: The harmony of the spheres: inducible nitric oxide synthase and related genes in pancreatic $\beta$ cells. Diabetologia 39: 875-890, 1996.

7. Corbett JA, Wang JL, Sweetland MA, Lancaster JR Jr and McDaniel ML: Interleukin $1 \beta$ induces the formation of nitric oxide by $\beta$-cells purified from rodent islets of Langerhans. Evidence for the B-cell as a source and site of action of nitric oxide. J Clin Invest 90: 2384-2391, 1992.

8. Cunningham JM and Green IC: Cytokines, nitric oxide and insulin secreting cells. Growth Regul 4: 173-180, 1994.

9. Welsh N, Eizirik DL, Bendtzen K and Sandler S: Interleukin-1ßinduced nitric oxide production in isolated rat pancreatic islets requires gene transcription and may lead to inhibition of the Krebs cycle enzyme aconitase. Endocrinology 129: 3167-3173, 1991.

10. Scarim AL, Heitmeier MR and Corbett JA: Irreversible inhibition of metabolic function and islet destruction after a 36-hour exposure to interleukin-1ß. Endocrinology 138: 5301-5307, 1997.

11. Heitmeier MR, Scarim AL and Corbett JA: Interferon- $\gamma$ increases the sensitivity of islets of Langerhans for inducible nitric-oxide synthase expression induced by interleukin 1. J Biol Chem 272: 13697-13704, 1997.

12. Oshima H, Taketo MM and Oshima M: Destruction of pancreatic B-cells by transgenic induction of prostaglandin E2 in the islets. J Biol Chem 281: 29330-29336, 2006.

13. Baeuerle PA and Henkel T: Function and activation of NF-кB in the immune system. Annu Rev Immunol 12: 141-179, 1994.

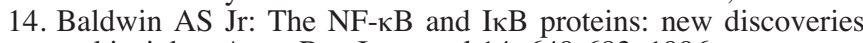
and insights. Annu Rev Immunol 14: 649-683, 1996.

15. May MJ and Ghosh S: Signal transduction through NF-кB. Immunol Today 19: 80-88, 1998.

16. Lv N, Song MY, Kim EK, Park JW, Kwon KB and Park BH:

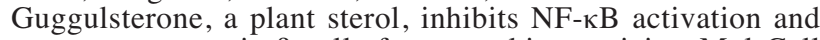
protects pancreatic $\beta$ cells from cytokine toxicity. Mol Cell Endocrinol 289: 49-59, 2008.

17. Kim EK, Kwon KB, Koo BS, et al: Activation of peroxisome proliferator-activated receptor- $\gamma$ protects pancreatic $\beta$-cells from cytokine-induced cytotoxicity via NFKB pathway. Int J Biochem Cell Biol 39: 1260-1275, 2007.

18. Cnop M, Welsh N, Jonas JC, Jorns A, Lenzen S and Eizirik DL: Mechanisms of pancreatic $\beta$-cell death in type 1 and type 2 diabetes: many differences, few similarities. Diabetes 54 (suppl 2): 97-107, 2005.

19. Eizirik DL and Mandrup-Poulsen T: A choice of death- the signal-transduction of immune-mediated $\beta$-cell apoptosis. Diabetologia 44: 2115-2133, 2001.

20. Donath MY, Storling J, Maedler K and Mandrup-Poulsen T: Inflammatory mediators and islet B-cell failure: a link between type 1 and type 2 diabetes. J Mol Med 81: 455-470, 2003.

21. Larsen CM, Wadt KA, Juhl LF, et al: Interleukin-1ß-induced rat pancreatic islet nitric oxide synthesis requires both the p38 and extracellular signal-regulated kinase 1/2 mitogen-activated protein kinases. J Biol Chem 273: 15294-15300, 1998.

22. Kim EK, Kwon KB, Song MY, et al: Genistein protects pancreatic $\beta$ cells against cytokine-mediated toxicity. Mol Cell Endocrinol 278: 18-28, 2007.

23. Lee JH, Song MY, Song EK, et al: Overexpression of SIRT1 protects pancreatic $\beta$-cells against cytokine toxicity through suppressing $\mathrm{NF- \kappa B}$ signaling pathway. Diabetes 58: 344-351, 2009.

24. Balla A, Toth B, Timar G, Bak J and Krajcsi P: Molecular targets for pharmacological cytoprotection. Biochem Pharmacol 61: 769-777, 2001

25. Yamamoto Y and Gaynor RB: Role of the NF-кB pathway in the pathogenesis of human disease states. Curr Mol Med 1: 287-296, 2001.

26. Kim EK, Kwon KB, Han MJ, et al: Inhibitory effect of Artemisia capillaris extract on cytokine-induced nitric oxide formation and cytotoxicity of RINm5F cells. Int J Mol Med 19: 535-540, 2007.

27. Kim EK, Song MY, Kim IS, et al: Beneficial effect of Flos magnoliae extract on multiple low dose streptozotocin-induced type 1 diabetes development and cytokine-induced $\beta$-cell damage. Int J Mol Med 22: 481-488, 2008.

28. Song MY, Kim EK, Moon WS, et al: Sulforaphane protects against cytokine- and streptozotocin-induced $\beta$-cell damage by suppressing the NF-кB pathway. Toxicol Appl Pharm 235: 57-67, 2009.

29. Evans JL, Goldfine ID, Maddux BA and Grodsky GM: Oxidative stress and stress-activated signaling pathways: a unifying hypothesis of type 2 diabetes. Endocr Rev 23: 599-622, 2002. 
30. Ho E, Chen G and Bray TM: Supplementation of N-acetylcysteine inhibits NFkB activation and protects against alloxaninduced diabetes in CD-1 mice. FASEB J 13: 1845-1854, 1999.

31. Scarim AL, Heitmeier MR and Corbett JA: Heat shock inhibits cytokine-induced nitric oxide synthase expression by rat and human islets. Endocrinology 139: 5050-5057, 1998.

32. Strandell E, Buschard K, Saldeen J and Welsh N: Interleukin-1ß induces the expression of hsp70, heme oxygenase and Mn-SOD in FACS-purified rat islet $\beta$-cells, but not in $\alpha$-cells. Immunol Lett 48: 145-148, 1995.

33. Sorli CH, Zhang HJ, Armstrong MB, Rajotte RV, Maclouf J and Robertson RP: Basal expression of cyclooxygenase-2 and nuclear factor-interleukin 6 are dominant and coordinately regulated by interleukin 1 in the pancreatic islet. Proc Natl Acad Sci USA 95: 1788-1793, 1998
34. Tran PO, Gleason CE, Poitout V and Robertson RP: Prostaglandin $\mathrm{E}_{2}$ mediates inhibition of insulin secretion by interleukin-1ß. J Biol Chem 274: 31245-31248, 1999.

35. Kwon KB, Park BH and Ryu DG: Chemotherapy through mitochondrial apoptosis using nutritional supplements and herbs: a brief overview. J Bioenerg Biomembr 39: 31-34, 2007.

36. Martin KR: Targeting apoptosis with dietary bioactive agents Exp Biol Med (Maywood) 231: 117-129, 2006.

37. Hong SH, Jeong HJ and Kim HM: Inhibitory effects of Xanthii fructus extract on mast cell-mediated allergic reaction in murine model. J Ethnopharmacol 88: 229-234, 2003.

38. An HJ, Jeong HJ, Lee EH, et al: Xanthii fructus inhibits inflammatory responses in LPS-stimulated mouse peritoneal macrophages. Inflammation 28: 263-270, 2004. 